\title{
Progressive improvement of atrial and ventricular capture thresholds, sensing, and impedances in epicardial pacing leads in young adults undergoing Fontan conversion
}

\author{
Mejora progresiva de los umbrales de captura auricular y ventricular, detección e \\ impedancias en los cables de estimulación epicárdica en adultos jóvenes que se someten \\ a conversión de Fontan
}

Jose M. Moltedo ${ }^{*}$, Mauricio S. Abello ${ }^{1}$, David Doiny ${ }^{1}$, Estela C. Falconi ${ }^{1}$, Carlos J Diaz ${ }^{1}$, María G. Majdalani ${ }^{1}$, and Bryan C. Cannon ${ }^{2}$

${ }^{1}$ Sanatorio Finochietto, Ciudad Autónoma de Buenos Aires, Argentina; ${ }^{2}$ Mayo Clinic, Rochester, Minnesota, USA

\begin{abstract}
Objectives: Patients with univentricular hearts who require permanent pacing systems typically require placement of epicardial leads. It is frequently difficult to find a position with good thresholds due to epimyocardial fibrosis or fat. The goal of the study is to assess the progression of capture thresholds (CT), sensing parameters ( $P$ waves and $R$ waves), and impedances (imp) of steroid eluting epicardial pacing leads in young adults who underwent Fontan conversion and a pacemaker implant. Methods: All patients undergoing Fontan conversion in two institutions were retrospectively identified. Demographic data, congenital heart defects, pacing leads used, and pacing parameters were analyzed at implant, at 6 weeks and 12 months after implant. Results: Twenty patients were identified (twelve males); mean age at conversion was $24.9 \pm 5.4$ years (range 18-35). Epicardial bipolar steroid eluting leads were used. The site of implant both in the atria and the ventricles varied depending on the parameters. At implant, mean atrial and ventricular impedances were $617 \pm 171 \Omega$ and $1061 \pm 771$ $\Omega$, respectively, mean $P$ wave amplitude was $2 \pm 0.7 \mathrm{mV}$, and mean $R$ wave amplitude was $12.5 \pm 7.7 \mathrm{mV}$. Mean $C T$ was $1.7 \pm 0.8 \mathrm{~V}$ at $0.5 \mathrm{~ms}$ for the atrium and $2.2 \pm 1.2 \mathrm{~V}$ at $0.5 \mathrm{~ms}$ for the ventricle. Ventricular CT and impedance showed an improvement within the first 12 months after implant, with four patients having a decrease in threshold of more than $2 \mathrm{~V}$. Conclusion: In patients undergoing Fontan conversion, implant ventricular CT and impedances are frequently higher than expected but typically improve during follow-up. Acceptance of higher initial threshold values may be a potential strategy in this patient population.
\end{abstract}

Key words: Fontan conversion. Pacing. Parameters. Progression.

\section{Resumen}

Objetivos: Los pacientes con corazón univentricular que requieren estimulación cardíaca reciben sistemas de estimulación epicárdicos. Debido a la presencia de fibrosis o grasa epi-miocárdica es dificultoso en esta población encontrar sitios con adecuados parámetros de estimulación. El objetivo de este estudio es determinar la progresión de los umbrales de captura,

Correspondence:

*Jose M. Moltedo

E-mail: jmoltedo @intramed.net
Available online: $23-02-2021$ Arch Cardiol Mex. 2021;91(4):439-443 www.archivoscardiologia.com 1405-9940 / @ 2020 Instituto Nacional de Cardiología Ignacio Chávez. Published by Permanyer. This is an open access article under the CC BY-NC-ND license (http://creativecommons.org/licenses/by-nc-nd/4.0/).

Date of reception: 12-09-2020

Date of acceptance: $20-11-2020$
DOI: $10.24875 /$ ACM.20000426 
los parámetros de sensado (medición de las ondas $P$ y $R$ ) e impedancias (imp) de los catéteres epicárdicos con liberación de esteroides implantados en adultos jóvenes sometidos a cirugía de reconversión de Fontan e implante de marcapasos. Métodos: Los pacientes sometidos a cirugía de reconversión de Fontan en dos instituciones fueron analizados retrospectivamente. Los datos demográficos, el tipo de cardiopatía congénita, de catéteres de estimulación y los parámetros de estimulación fueron analizados al momento del implante, a las 6 semanas y al año. Resultados: Se identificaron 20 pacientes (12 de ellos de sexo masculino); la edad media al momento de la reconversión fue de $24.9 \pm 5.4$ años (rango 18-35). Se utilizaron catéteres epicárdicos bipolares de fijación pasiva y con liberación de esteroides en todos los casos. El sitio de implante en las aurículas y en los ventrículos fue variable de acuerdo a los parámetros. En el momento del implante las impedancias medias fueron $617 \pm 171 \Omega$ y $1061 \pm 771 \Omega$ respectivamente, la amplitud media de la onda $P$ fue $2 \pm 0.7 \mathrm{mV}$ y la media de amplitud de la onda $R$ fue de $12.5 \pm 7.7 \mathrm{mV}$. Las medias de los umbrales de captura fueron $1.7 \pm 0.8 \mathrm{~V}$ at $0.5 \mathrm{~ms}$ para los catéteres auriculares y $2.2 \pm 1.2 \mathrm{~V}$ at $0.5 \mathrm{~ms}$ para los ventriculares. Los umbrales de captura y las impedancias ventriculares mostraron una mejoría en los 12 meses posteriores al implante, y en 4 pacientes esa mejoría en el umbral de captura ventricular fue mayor a $2 \mathrm{~V}$. Conclusiones: En pacientes sometidos a una cirugía de reconversión de Fontan e implante de marcapasos, los umbrales de captura e impedancias ventriculares son más elevados que los esperados, pero mejoran durante el seguimiento. La aceptación de valores más elevados puede potencialmente constituir una alternativa en esta población de pacientes.

Palabras clave: Reconversión. Parámetros de estimulación. Progresión.

\section{Introduction}

The Fontan procedure described in the early 1970's has allowed for improvement in the survival of many patients with univentricular hearts. However, over time, significant complications may develop, including ventricular dysfunction, thromboembolic events, and arrhythmias, among others. One of the available therapeutic options for patients with hemodynamic abnormalities and a failing Fontan circulation is conversion to a total cavopulmonary anastomosis, with atrial reduction and arrhythmia surgery ${ }^{1}$. Because of the risk of sinus node dysfunction and long-term atrial arrhythmias, many patients have a permanent pacing system implanted at the time of their Fontan conversion. However, placement of these pacing systems can be technically challenging.

Fontan patients most commonly have epicardial systems placed. Transvenous leads incur a $>2$ fold increased risk of systemic thromboembolism in patients with intracardiac shunts, with annualized rates of systemic thromboembolism of around $2 \%^{2}$. Based on the American College of Cardiology/American Heart Association 2008 Guidelines for the Management of Adults with Congenital Heart Disease, epicardial pacemaker and device lead placement should be performed in all cyanotic patients with intracardiac shunts who require devices (Class I indication) ${ }^{3}$. There is also concern about thrombus formation on leads within the Fontan circuit due to the low flow states seen in many Fontan patients. These thrombi then may embolize to the lungs and create problems. In addition, patients also have limited venous access to the heart for placing transvenous leads following the Fontan operation 4 . However, due to previous operations and the hemodynamic strain that single ventricle physiology places on the heart, the epi-myocardium of these hearts is frequently densely lined with fat or fibrous tissue creating difficulty in locating epicardial pacing sites with good stimulation and sensing parameters ${ }^{5,6}$.

With the advent of steroid eluting leads, there is frequently an improvement in the capture thresholds (CT) for leads over the initial implantation values. However, the degree of improvement, particularly for leads in patients with extensive scarring as seen in the Fontan patients undergoing conversion to a total cavopulmonary anastomosis and concomitant arrhythmia surgery and a permanent pacemaker implant, has not been extensively studied.

The objective of this study is to assess the progression of $C T$, sensing parameters ( $P$ waves and $R$ waves), and impedances of steroid eluting epicardial pacing leads in young adults who underwent Fontan conversion with the implant of a permanent pacemaker.

\section{Materials and methods}

All patients who underwent Fontan conversion and the implant of a permanent epicardial pacing system in two different institutions from January 2003 and December 2012 were identified. Demographic data and details of the cardiac anatomy were retrospectively analyzed. Institutional review board approval was obtained at both institutions. 
Atrial and ventricular leads were placed during the Fontan conversion procedure, using standard implant techniques and following the lead manufacturer recommendations. Passive fixation, bipolar, and steroid eluting epicardial leads (Medtronic 4968 CapSure Epi, Medtronic Corp; Minneapolis, MN) were used in all cases and these were tunneled to the abdomen where the generator pocket was created.

In all cases, implant measurements were obtained following the standard techniques: atrial and ventricular impedances were assessed, sensing was measured by evaluation of intrinsic atrial and ventricular signals amplitudes, and stimulation voltage thresholds were evaluated at a pulse width of $0.5 \mathrm{~ms}$. The atrial and ventricular sites of the implant were variable and independent of the type of congenital heart disease, and it depended on the previously mentioned pacing parameters.

Repeat values were obtained at routine follow-up 6 weeks and 12 months after implant. During the visits, the pacemaker system was interrogated, and atrial and ventricular impedance, $P$ and $R$ wave's amplitudes, and stimulation thresholds were measured. Ambulatory 24-h continuous electrocardiogram monitoring was regularly performed at 6 weeks and 12 months after implant, and then yearly or depending the individual care provider for the patient. Any pacing abnormalities or issues noted on the Holter were noted.

A repeated measures analysis of variance was performed with the level of significance set at 0.05. SAS 9.3 (SAS Institute, Inc., Cary, North Carolina) was used for the analysis.

\section{Results}

Twenty patients were identified. There were 8 females and 12 males with a mean age at the time of Fontan conversion to the total cavopulmonary anastomosis and pacemaker implant of $24.9 \pm 5.4$ years (range 18-35). Congenital diagnoses included tricuspid atresia $(n=9)$, $D$ or $L$ transposition of the great arteries with atrioventricular valve atresia or ventricular hypoplasia $(n=7)$, double inlet left ventricle $(n=2)$, and hypoplastic left heart syndrome $(n=2)$.

\section{Implant data}

Impedances were $617 \pm 171 \Omega$ for the atrium and $1061 \pm 771 \Omega$ for the ventricle. The $\mathrm{P}$ wave amplitude was $2 \pm 0.7 \mathrm{mV}$ and $R$ wave amplitude was $12.5 \pm 7.7 \mathrm{mV}$. Voltage CT were $1.7 \pm 0.8 \mathrm{~V}$ at $0.5 \mathrm{~ms}$ for the atrium and $2.2 \pm 1.2 \mathrm{~V}$ at $0.5 \mathrm{~ms}$ for the ventricle.

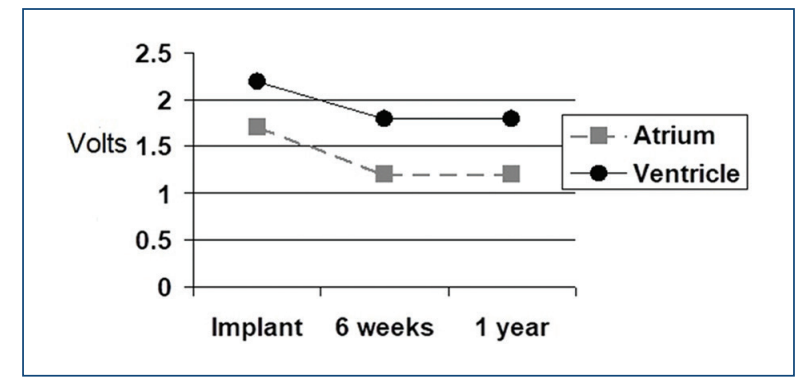

Figure 1. Capture thresholds at implant and during followup. These values were always assessed at a pulse width of $0.5 \mathrm{~ms}$.

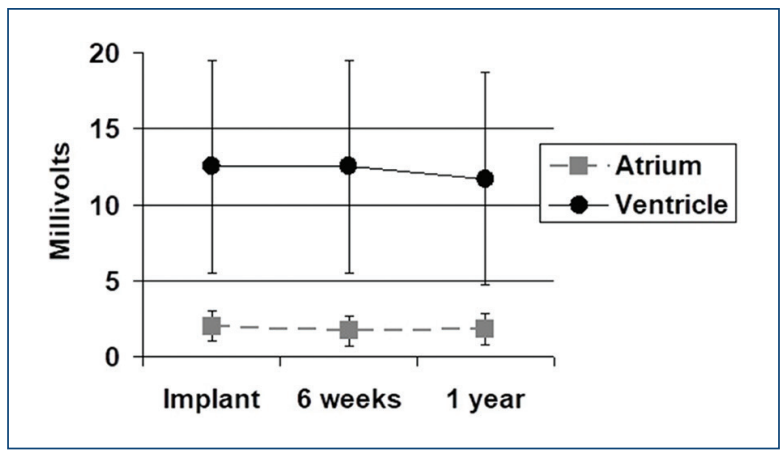

Figure 2. Sensing parameters at implant and during follow-up.

\section{Follow-up data}

Atrial and ventricular impedances, $\mathrm{P}$ wave and $\mathrm{R}$ wave sensing, and atrial and ventricular CT were measured at follow-up visits. The atrial CT had decreased to $1.2 \pm 0.5 \mathrm{~V}(p=0.02)$ at 6 weeks and remained stable 1 year after placement. The ventricular CT had decreased to $1.8 \pm 1.2 \mathrm{~V}(\mathrm{p}=0.01)$ at 6 weeks and remained stable 1 year after placement (Fig. 1). The atrial and ventricular sensing parameters remained relatively constant throughout follow-up. The $P$ wave amplitude was $1.7 \pm 0.9 \mathrm{mV}$ at 6 weeks and $1.8 \pm 0.8 \mathrm{mV}$ 1 year after placement. The $\mathrm{R}$ wave amplitude was stable at $12.3 \pm 7.5 \mathrm{mV}$ at 6 weeks and was $11.2 \pm 5.7 \mathrm{mV}$ 1 year after placement (Fig. 2). The atrial impedance had decreased to $536 \pm 94 \Omega$ at 6 weeks and $558 \pm 96$ $\Omega 1$ year after placement. The ventricular impedance had decreased to $536 \pm 203 \Omega$ at 6 weeks and $492 \pm$ $182 \Omega 1$ year after placement (Fig. 3). Within 6 months of placement, $4 / 20(20 \%)$ of patients had an improvement in ventricular CT of more than 2 volts compared to implantation, likely from acute epicardial 


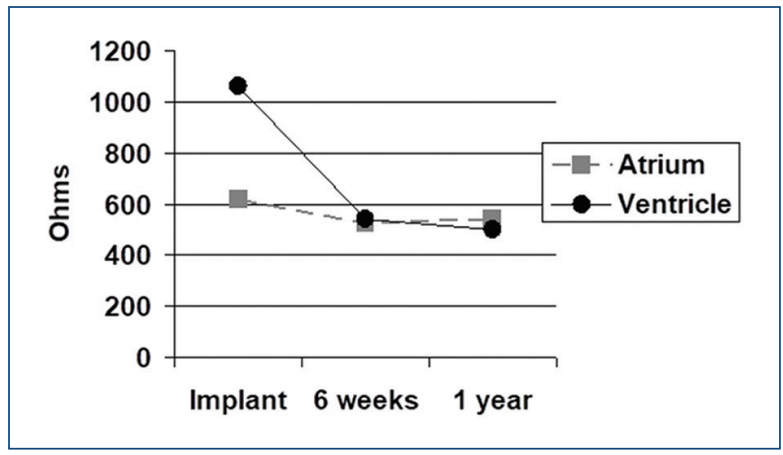

Figure 3. Lead impedances at implant and during follow-up.

inflammation in already diseased myocardium. All patients were noted to have normal pacemaker function with no abnormalities on follow-up Holter monitoring

\section{Discussion}

Pacemaker device and lead technology have improved significantly over the last 15 years, providing a better technical solution to difficult clinical situations. These advancements have made pacemaker placement possible in more patients with structural congenital heart disease. Despite there is previously published data about the short, medium, and long-term progression of pacing parameters in patients with congenital heart defects (bi and univentricular physiologies) ${ }^{5,7}$, this is, to the best of our knowledge, the first one addressing this issue in the population of young adults with univentricular hearts undergoing a Fontan conversion to a total cavopulmonary anastomosis with concomitant arrhythmia surgery and permanent pacemaker placement.

In Fontan conversion patients, lead placement may be difficult due to the presence of multiple factors that may potentially interfere with acute pacing and sensing parameters. These factors include epi-myocardial fibrosis and fat, the effect of cardiopulmonary by-pass or electrolyte abnormalities, or air interposed between the electrode and the myocardium. Frequently multiple sites must be tried on the atrium and ventricle to find a position where the sensing and stimulation thresholds are acceptable for long-term pacing both in the context of setting the pacemaker with an adequate safety margin and trying to preserve battery life with low stimulation output. In this series of patients, pacing and sensing parameters at implant, specifically atrial and ventricular $\mathrm{CT}$, were higher than previously reported data with steroid eluting pacing electrodes $5,7,8$.
Ventricular impedances were also higher than previously reported, particularly in the ventricular lead at implant ${ }^{5,7}$. This finding may be attributed to the higher tendency to scar tissue formation of the myocardium compared to the atrium or to a potential difference in the response of the ventricular myocardium to the local inflammation caused by suturing leads onto the myocardium. Another possible explanation for this finding is that these cohort patients were older at the time of implant than patients included in other series ${ }^{7}$. Although the pacing stimulation thresholds and ventricular impedances were affected, most likely due to epi-myocardium fibrosis, there was no significant change in the $P$ wave and $R$ wave sensing values.

As opposed to previously reported data, in this patient cohort, a decrease in the ventricular CT was observed during the $1^{\text {st }}$ year of follow-up ${ }^{7}$. This finding may be attributed to the technical characteristics of the utilized leads, mostly the steroid eluting feature that mitigates the local inflammatory response that affects the electrode-myocardium interface ${ }^{5,7,8}$. In previously presented data in Fontan patients and also with biventricular repair for congenital heart defects, the leads were not always steroid eluting? ${ }^{7}$. As previously reported, atrial CTs showed an improvement, with very good chronic values at 12 months after implant ${ }^{7,8}$. This effect is likely longer lasting as it has been shown that $20 \%$ of steroid remains in place after 4 years in explanted electrodes and the long-term durability of the leads requires further evaluation ${ }^{9}$.

There are limitations in this study. The first one is the number of patients that affects the strength of the obtained conclusions. However, it is interesting data that should be considered in clinical practice in this unique population. The second limitation is determined by the fact of the heterogeneity of these patients in regard to the anatomy, the number of previous surgical procedures and individual variations in the fibrous reaction.

\section{Conclusions}

In young adults undergoing Fontan conversion to a total cavopulmonary anastomosis and placement of a permanent epicardial pacing system using bipolar steroid eluting leads, implant ventricular CT and impedances can be higher than in other patient populations with congenital heart defects. However, these parameters typically improve during follow-up and therefore accepting higher initial values during epicardial lead placement is a potentially viable strategy in this patient population. 


\section{Funding}

None.

\section{Conflicts of interest}

None.

\section{Ethical disclosures}

Protection of human and animal subjects. The authors declare that no experiments were performed on humans or animals for this study.

Confidentiality of data. The authors declare that no patient data appear in this article.

Right to privacy and informed consent. The authors declare that no patient data appear in this article.

\section{References}

1. Mavroudis C, Backer CL, Deal BJ, Johnsrude CL. Fontan conversion to cavopulmonary connection and arrhythmia circuit cryoablation. J Thorac Cardiovasc Surg. 1998;115:547-56.
2. Khairy P, Landzberg MJ, Gatzoulis MA, Mercier LA, Fernandes SM, Côté JM, et al, Epicardial Versus Endocardial Pacing and Thromboembolic Events Investigators. Transvenous pacing leads and systemic thromboemboli in patients with intracardiac shunts: a multicenter study. Circulation. 2006;113:2391-7.

3. Warnes CA, Williams RG, Bashore TM, Child JS, Connolly HM, Dearani JA, et al. ACC/AHA 2008 guidelines for the management of adults with congenital heart disease: a report of the American college of cardiology/American heart association task force on practice guidelines (writing committee to develop guidelines on the management of adults with congenital heart disease). Developed in collaboration with the American society of echocardiography, heart rhythm society, international society for adult congenital heart disease, society for cardiovascular angiography and interventions, and society of thoracic surgeons. J Am Coll Cardiol. 2008;52:e143-263.

4. Cohen MI, Rhodes LA, Spray TL, Gaynor JW. Efficacy of prophylactic epicardial pacing leads in children and young adults. Ann Thorac Surg. 2004;78:197-203.

5. Cutler NG, Karpawich PP, Cavitt D Hakimi M, Walters HL. Steroid-eluting epicardial pacing electrodes: six year experience of pacing thresholds in a growing pediatric population. Pacing Clin Electrophysiol. 1997; 20:2943-48

6. Sachweh JS, Vazquez-Jimenez JF, Schondube FA, Daebritz SH, Dörge H, Mühler EG, et al. Twenty years with pediatric pacing: epicardial and transvenous stimulation. Eur J Cardiothorac Surg. 2000;17:455-61.

7. Lau KC, Gaynor JW, Fuller SM, Smoots KA, Shah MJ. Long-term atrial and ventricular epicardial pacemaker lead survival after cardiac operations in pediatric patients with congenital heart disease. Heart Rhythm. 2015;12:566-73.

8. Cohen MI, Vetter VL, Wernovsky G, Bush DM, Gaynor JW, Iyer VR, et al. Epicardial pacemaker implantation and follow-up in patients with a single ventricle after the fontan operation. J Thorac Cardiovasc Surg. 2001;121:804-11.

9. Stokes KB. Controlled Release of Steroid to Enhance Pacemaker Performance. Alabama: Proceedings of the $13^{\text {th }}$ Annual Meeting of the Society of Biomaterials; 1987. p. 52. 